\title{
Modern Marketing Management and New Trends in Marketing
}

\author{
Elshad Mammadbayov ${ }^{1, *}$ Ratih Hurriyati ${ }^{2,}$ Heny Hendrayati ${ }^{3}$
}

\author{
${ }^{1}$ Universitas Pendidikan Indonesia \\ ${ }^{2}$ Universitas Pendidikan Indonesia \\ ${ }^{3}$ Universitas Pendidikan Indonesia \\ *Corresponding author. Email: memmedbey@gmail.com
}

\begin{abstract}
Marketing in businesses is one of the most critical business functions that enable the business to survive and move forward with firm steps. It is not possible to think of a business without marketing. So much so that today, competition conditions have become challenging in the globalizing world in parallel with technology. The consumer can easily purchase a product produced in any corner of the world in another corner of the world via e-commerce or other methods. This makes the already existing global competition even more intractable. In these challenging competitive conditions, manufacturers or service providers carry out marketing activities to get a share from the target market to survive, grow, and ensure continuity. The fact that companies can survive and grow under these fierce competition conditions is only possible if their products and services can be different from their competitors by providing more customer satisfaction. It is up to the company's marketing department to explain the different aspects of the businesses, the quality of their products, and customer satisfaction. Today, it has been revealed that these marketing activities cannot be done with the marketing activities from the past. This means businesses have stepped out of the classical marketing concept and implemented modern marketing management and techniques targeting the individual customer base. Companies that have absorbed the modern marketing concept and can apply new marketing trends are one step ahead. Companies that cannot keep up with these trends rapidly lose their market shares and withdraw from the market over time.
\end{abstract}

Keywords: modern marketing, marketing trends, marketing management.

\section{INTRODUCTION}

It is a fact known by all times that competition is increasing in every field today. Nowadays, due to the increasing competition between businesses, businesses are obliged to carry out marketing activities to increase their sales and get ahead of their competitors. In today's globalizing world, all businesses, regardless of whether they are small or large, produce goods and services, carry out marketing activities in different ways to exist in the market.

The developing technology in recent years has also changed the way of marketing in parallel. Some formerly existing marketing methods are being replaced by more different modern marketing techniques brought by technology [1]. For example, newspaper ads, which were much more important in marketing in the past, are gradually being replaced by digital marketing. Again, the classic billboard advertisements, which were made before, are shifting their place to internet advertisements or marketing techniques we call guerrilla marketing. This is because, in parallel with the developing technology, the effect of old marketing techniques on people is reduced.

Although we will discuss modern marketing techniques, the issue of marketing, with its old and new techniques, has remained significant in the past, today 
and will be of great importance for profit-making or non-profit businesses in the future. For this reason, marketing is an activity that must be implemented for the survival and growth of businesses. In this study, current marketing trends will be analyzed in the context of changing competition conditions.

\subsection{Modern marketing management practices and new trends in marketing}

The main goal in marketing efforts from the past to the present has been to provide new reasons for customers to buy something new. Subsequently, with the marketing transformation that started in the 2000s, the primary purpose has begun to reveal reasons to make consumers talk about the brand. Today, the brands' communication strategies have been developed, and there has been a transition from one-way marketing communication to two-way marketing communication. Subsequently, the communication channels used with the integrated marketing approach communication are developed and diversified.

\subsection{Below are some of the trends for some new markets applied by companies today}

- $\quad$ Green Marketing

- Guerilla Marketing

- Database Marketing

- Interactive Marketing (Viral Marketing)

- Word of Mouth Marketing

- Internet Marketing

As above, new marketing trends have come from the 2000 s to the present and continue. Today, many companies are implementing these new marketing strategies.

With the development of digital technology in parallel with the development of technology in recent years, it has become effortless to process a wide range of information. The possibilities brought by technological developments have created a broad market with globalization. Likewise, getting to know the market and reaching the target audiences in the market has become very easy with technological possibilities. New marketing techniques created by digitalizing information have created great opportunities for marketing management. At the beginning of this is database systems, which we can accept as a blessing of technology. In traditional marketing methods, getting and collecting information about customers is not seen as vital as it is now, and in terms of technology, it did not seem possible to apply it. Nowadays, the need for collecting, storing, storing, and evaluating data in the target market with the marketing communication techniques of the enterprises constitutes the basis of today's modern marketing management. The concept of database marketing has emerged with the increasing use of computers by today's businesses. In this way, it is possible to make various analyses for marketing with databases related to customers, products, and functions and establish marketing strategies in light of this information.

Three essential features can be mentioned for a company to be able to do database marketing. These are data, strategy, and analysis tools, respectively:

\section{- Data}

The information that businesses will obtain from databases for marketing strategies is directly related to the databases' content, that is, the type and scope of the data. In addition to these, the quality and type of data positively affect customer loyalty. In database marketing, it is essential for companies to know the customer's birth and wedding anniversary information or to know the customer's lifestyle information. While changing from sector to sector, the information that should be available in the database is identity information, address information, economic data, lifestyle data, purchasing information, basically, customer information that can be said. Businesses should first start by collecting such data in databases.

- Strategy

To make an accurate and effective database marketing, it is necessary to create a perception in the company and determine the strategy for this. Database marketing affects many management levels within the company, starting from the salesperson in the field to the marketing staff in the center and the management level. For the units to work effectively and in coordination, the database strategy should be determined well. With the information obtained through the in-house database, it is necessary to determine which customers will be approached and strategies for this purpose. The database's information will be selected and used for the proper purpose in line with these developed strategies.

- Analysis Tools

Another essential issue to using database marketing effectively is the database analysis tools. These can be grouped into three categories: reports, mathematical models, and data mining.

Reports; It is the traditional method used to obtain the required data from a computer system. In general, it can be divided into two parts as private and renewable. A renewable report is a type of report prepared according to different schedules such as weekly and monthly. Users can receive renewable reports automatically according to specific time intervals 
without requesting them. Special reports, on the other hand, are reports prepared due to a particular need for information. Asking a question about a subject to the database can be considered as a unique report.

Mathematical Modeling; The reports show what has been done in the past and what is being done now. However, users of information systems and managers at the decision-making level also want to see the future. To see or predict the future can be achieved with mathematical models. Mathematical models are prepared by using past data and observations. Practitioners try to predict possible future results by modeling the data they have in a suitable simulation program. Data mining; Customer expectations are increasing, and it is getting harder and harder to satisfy customers. With communication technologies, customers become effortless to reach alternative products, which gradually decreases customer loyalty. Companies, on the other hand, want to keep profitable customers in a competitive environment. As a result, businesses try to understand customer needs and respond to them quickly. For success, businesses have to anticipate customer demands and expectations. Many businesses today are aware of this situation and collect information about their customers' preferences and expectations. Businesses collect detailed information about their customers, markets, products, and methods on different programs. Data mining uses this information to create new opportunities and to determine the future strategy of the business. Data alone are worthless, but these data become meaningful when processed for a specific purpose. The transformation of raw data into information is done by data mining. Data mining is the ability to retrieve valuable information from a vast data warehouse.

\section{RESULT AND DISCUSSION}

With the developing technology, production technologies have developed rapidly, and production has become fast, high in quality, and much more manageable. In parallel with the developing technology, information systems, and the internet have become the indispensable technology of today. In parallel with the development of the internet, the world has gained a global structure, and thanks to the marketing made on the internet, products produced in any part of the world have become easily found and purchased by the whole world. This has increased the global competition as much as possible today. Companies have accelerated their marketing activities to take the lead and survive in this cutthroat competitive environment. The knowledge level of consumers has increased in the increasingly competitive environment. This situation has caused classical marketing management techniques to be insufficient, and modern marketing management techniques used today have replaced classical marketing techniques.

In the field of marketing, the necessity and effects of modern marketing management are seen today. In modern marketing management techniques, issues such as brand awareness, advertising, customer relations, public relations have come to the fore. Companies try to carry out their marketing activities by considering these issues in their marketing activities. As can be seen from here, the concept of customer has gained significant importance in the field of marketing. Firms try to be in a one-on-one relationship and establish relationships with their customers. In the researches, it has been observed that the companies that dominate the market and that are the leading companies establish closer relations with their customers, understand and analyze their needs and expectations well and produce suitable solutions for them.

Establishing relationships with customers and being in a one-on-one relationship will be possible by taking advantage of today's technological opportunities. Therefore, companies have to use the internet technologies, which is the technological communication system of our day. Today's companies use different communication techniques of internet technologies such as website, e-mail, website optimization in their marketing activities in modern marketing management. The importance of the internet in today's and future modern marketing techniques is an indisputable fact. Companies that cannot integrate the concept of the customer with technology will not have a chance to live in the future.

\section{CONCLUSION}

It is of great importance that companies make these relationships permanent and the good relations established with the customers in the competitive conditions that come with technology and globalization. Permanent relationships with customers can only be possible by following different trends, changes, developments, and customer expectations in their markets and responding quickly to customer requests and expectations. In this way, masses of loyal customers who can make continuous purchases will be created. On the other hand, the loyal customers' concept has become an easy way for companies to reach new customers. Loyal and satisfied customers will recommend the company and products to their environment, which will mean opening new customers' doors for the company.

In this environment where competition is increasing, companies that produce or provide services rightly carry out various marketing activities to get ahead in the intense competition. This directs companies to the current new marketing trends. Companies are obliged to apply modern marketing trends in line with the quality 
of the product or service. In fact, they are obliged to reveal their differences by creating unique and different marketing trends that cannot be predicted. There is no chance of life in the world for companies that try to walk with classical marketing methods. Companies should try to be flexible, follow all kinds of innovations and take part in the market by changing the shell very quickly when necessary. Because in parallel with technology, the concept of marketing and market is constantly changing rapidly, as in every field. Many things such as new trends, new products, and new concepts appear before the business every day. Marketing management in businesses should be prepared for such situations and be able to respond quickly when necessary.
Sales and marketing activities on the internet have become the most important competitive weapon of today's companies. Marketing and sales activities over the internet reached an unpredictable extent 10 years ago. Today, everything from food to clothing, health to education, and electronics can be easily purchased online. Customers' trust in the internet is rapidly increasing, which shows that the e-commerce event to be made on the internet will reach much higher levels in the future.

\section{REFERENCES}

[1] 10 Principles of Modern Marketing. MITSloan Management review. April 03, 2019. [Online]. Avaible: https://sloanreview.mit.edu/article/10-principles-of-modernmarketing/. 